\author{
WIOLETTA JEDLECKA \\ ORCID: 0000-0002-0542-9303 \\ Uniwersytet Wrocławski \\ Katedra Teorii i Filozofii Prawa
}

\title{
ZAKAZ STOSOWANIA KAR CIELESNYCH A KONTRATYP KARCENIA WYCHOWAWCZEGO
}

\begin{abstract}
Abstrakt: Prezentowany artykuł jest poświęcony relacji między wprowadzonym w przepisie art. $96^{1}$ kodeksu rodzinnego i opiekuńczego zakazem stosowania kar cielesnych a funkcjonującym w prawie karnym kontratypem karcenia wychowawczego. Analiza zagadnień związanych z tematem artykułu pokazuje, jaki wpływ ma zakaz wyrażony art. $96^{1}$ kodeksu rodzinnego i opiekuńczego na kontratyp karcenia, oraz pozwala sformułować wnioski w zakresie skuteczności tegoż zakazu. Praktyczna waga omawianych kwestii wynika z powszechności zjawiska stosowania różnych form karcenia wobec dzieci.
\end{abstract}

Słowa kluczowe: zakaz stosowania kar cielesnych, pozaustawowy kontratyp karcenia wychowawczego, prawo rodzinne, prawo karne

\section{POJECIE KARCENIA}

Karcenie postrzegane jest jako jeden z czynników, które mają za zadanie regulowanie postępowania jednostki. Karcenie może też stanowić dolegliwość o charakterze fizycznym bądź psychicznym, która dotyka osoby dopuszczającej się naruszenia ustalonych reguł wyznaczających pewne sposoby postępowania. Można zatem stwierdzić, że karcenie zawiera dwa elementy: (1) niepożądany czyn i (2) karę jako nieprzyjemne przeżycie ${ }^{1}$.

Bez wątpienia karcenie dzieci jest jednym z najbardziej złożonych społecznie zagadnień, ponieważ podlegającym odmiennym ocenom aprobaty i dezaprobaty dla praktyk wychowawczych, w ramach których rodzice bądź inne osoby odpowiedzialne za dziecko odwołują się do jego karcenia. Oceny te są warunkowane określoną tradycją kulturową, gdyż głoszenie na szerszą skalę, że trzeba starać się oddziaływać na małoletnich bez sięgania zwłaszcza do ich fizycznego karcenia, ma miejsce w sumie od niedawna, co odnosi się też do wprowadzania

1 Zob. S. Różycka-Jaroś, Karcenie dzieci - czyn zabroniony czy okoliczność uchylająca bezprawność, Warszawa 2012, s. 28-29. 
prawnych zakazów stosowania kar cielesnych oraz innych niewłaściwych metod wychowawczych wobec dzieci. Refleksja, że stosowanie wobec dzieci kar fizycznych w ogóle nie powinno mieć miejsca, przyszła dosyć późno, a pochodziła od myślicieli społecznych i osób działających na rzecz dzieci i ich praw, których idee w tym zakresie bardzo wolno wpływały na prawodawstwo poszczególnych państw ${ }^{2}$.

T. Bojarski uważa, że różne formy karania, nie tylko fizycznego, wolno uznać za formę karcenia. Obok karcenia fizycznego mogą być stosowane inne sposoby, a także inne formy oddziaływania słownego na małoletniego, a ponadto wprowadzanie ograniczeń ich praw. Karcenie to nie tylko oddziaływanie cielesne, lecz także ustny wytyk, wskazanie wad, pogróżka, ograniczenie wolności czy ograniczenie praw osobistych, jak na przykład udział w spotkaniu koleżeńskim czy uczestniczenie w imprezie sportowej bądź rozrywkowej. Karcić to inaczej strofować, ukrócać. Karcenie więc to wyrządzenie dolegliwości, ale celowe, po to, aby doprowadzić do świadomości innej osoby, że jej czyn jest naganny, i aby ta osoba w przyszłości zmieniła swą postawę. Karcenie wykazuje przy tym pewną łączność z karą, ale w pojęciu karcenia wyraźniej jest wskazany moment oddziaływania wychowawczego niż w pojęciu kary; poza tym karcenie jest dolegliwością łagodniejszą aniżeli kara kryminalna. Sens karcenia polega zatem na wyrządzeniu określonych dolegliwości, aby osiągnąć cel wychowawczy. Karcenie fizyczne sprawia dolegliwość w sensie fizycznym, podczas gdy pozostałe formy karcenia też są dolegliwe, ale ta dolegliwość jest innej natury. Wywołują one bowiem dyskomfort psychiczny w postaci uświadomienia sobie własnych błędów, własnej słabości, ujemności charakteru. Można więc mówić w tym wypadku o dolegliwości natury psychicznej, moralnej, odczuwanej przez małoletniego ${ }^{3}$.

Można w tym miejscu dodać, że zwyczajowe formy karcenia dzieci w Polsce są ściśle związane ze stosowaną wobec nich przemocą fizyczną, ekonomiczną, psychiczną i seksualną. Trudno doszukiwać się takich form i sposobów karcenia dzieci, aby można było o nich powiedzieć, że mieszczą się w pojęciu „karcenia wychowawczego". Kara, karcenie wychowawcze powinno być świadomym zabiegiem wychowawczym nienaruszającym godności i integralności cielesno-duchowo-psychicznej dziecka. Tak pojęta kara powinna mieć raczej cechy sankcji negatywnej - pozytywnej wychowawczo, która uczy i wychowuje dziecko, dając mu przy tym możliwość poprawy swego nieprawidłowego zachowania ${ }^{4}$.

$\mathrm{Z}$ wychowawczego punktu widzenia jedynie taka kara ma sens, która pozwala doświadczyć karanemu tego, że potrafi postępować inaczej, lepiej, zgodnie z obowiązującymi normami społecznymi. $Z$ tego samego punktu widzenia niebez-

2 R. Krajewski, Karcenie dzieci. Pespektywa prawna, Warszawa 2010, s. 127.

3 T. Bojarski, Zakres kontratypu karcenia małoletnich w polskim prawie karnym, [w:] Prawne aspekty karcenia małoletnich, red. F. Ciepły, Warszawa 2011, s. 21-22.

${ }^{4}$ M.E. Ruszel, Zwyczajowe formy karcenia wychowawczego dzieci w społeczeństwie polskim, [w:] Prawne aspekty..., s. 159. 
pieczne jest także nadużywanie kar, gdyż wiedzie to w konsekwencji ku utracie zaufania, niechęci, kłamstwu i wyzwala skłonność do używania agresji. Jest poza tym przyczyną frustracji, lęku, niepewności i sprzyja kształtowaniu się poczucia niższości. A w takich warunkach trudno mówić o prawidłowym rozwoju dziecka. Należy przy tym pamiętać, że kara to ostateczność, częściej powinno się dzieci nagradzać niż karać, jako że sam brak nagrody jest już dla dziecka rodzajem kary5.

Zgadzam się z twierdzeniem, że tak pojęty proces karcenia dzieci, po pierwsze, spełnia wymogi skuteczności stosowania kar z punktu widzenia pedagogicznego, a po drugie, nie koliduje $\mathrm{z}$ aktualnym stanem prawnym obowiązującym w RP.

\section{ASPEKTY PRAWNE FIZYCZNEGO KARCENIA DZIECI}

Przepisy zakazujące wprost fizycznego karcenia dzieci zaczęły pojawiać się w państwach europejskich w drugiej połowie XX wieku. Ich wprowadzenie do porządku prawnego wzbudzało podobne emocje jak wcześniejsze regulacje zabraniające bicia żony lub służącego przez pana domu, czeladników przez majstrów czy uczniów przez nauczycieli. Zakres dopuszczalności karcenia małoletnich w państwach europejskich ulega stałemu, powolnemu zwężaniu. Dyskutuje się też szeroko nad sposobami oddziaływań wychowawczych, postulując całkowity zakaz naruszania nietykalności fizycznej dziecka ${ }^{6}$.

W ustawodawstwie polskim nie ma jeszcze jednoznacznego zakazu stosowania wobec dzieci i młodzieży karcenia fizycznego. Artykuł 40 Konstytucji RP zawiera jedynie przepis mówiący o zakazie stosowania kar cielesnych. Celem istnienia przedmiotowego przepisu jest uczynienie nielegalnymi zachowań wymierzonych przeciwko samej naturze człowieka i przy tym jego godności ${ }^{7}$. Poniekąd zgodnie z poglądem doktryny adresatem tej normy jest jedynie władza publiczna i omawiany przepis odnosi się do stosowania i wykonywania kar w imieniu państwa. Nie jest to zatem norma prawna, która prowadziłaby do delegalizacji karcenia z użyciem przymusu fizycznego w relacji rodzic-dziecko. W polskim prawie nie ma jednakże żadnego przepisu, który — jak ma to miejsce na przykład w Kanadzie — w sposób jednoznaczny przyzwalałby na stosowanie wobec małoletnich kar fizycznych. Tego rodzaju uprawnienia nie przewiduje ani kodeks rodzinny i opiekuńczy, który nie wypowiada się co do dopuszczalności metod i środków wychowawczych, ani żaden inny akt ustawodawczy. Karcenie nieletnich może stanowić czyn wypełniający znamiona przestępstw, jednakże dokonywane przez

5 Z. Frączek, Nagrody i kary w wychowaniu rodzinnym, „Pedagogika Rodziny” 2014, nr 4, s. 53.

${ }^{6}$ F. Ciepły, Partnerstwo $w$ rodzinie a prawnokarny kontratyp karcenia małoletnich, [w:] Partnerstwo w rodzinie. Istota i uwarunkowania relacji między rodzicami a dziećmi, red. J. Truskolaska, Lublin 2009, s. 257 n.

7 Wyrok TK z dnia 1 czerwca 1999 roku, sygn. SK 20/98, OTK 1999, nr 5, poz. 93. 
rodziców czy opiekunów w celach wychowawczych z całą pewnością nie może wykraczać poza ustalone zdrowym rozsądkiem oraz prawem granice ${ }^{8}$. P. Czarnek jest zdania, że w ujęciu konstytucyjnym należy przyjąć, że kary fizyczne wobec dzieci są dopuszczalne tylko wtedy, gdy są stosowane dla dobra dziecka, czyli w celach wychowawczych, to jest wówczas, gdy inne środki okazały się nieskuteczne oraz gdy stosowane są w taki sposób i w takich okolicznościach, że nie naruszają godności dziecka, a zwłaszcza nie powodują u niego poczucia poniżenia. Dopiero stosowanie kar cielesnych w innych okolicznościach jest sprzeczne z przepisem art. 40 Konstytucji i w związku z art. 30 Konstytucji jest biciem ${ }^{9}$.

Nie podzielam tego poglądu, bo co to znaczy „w innych okolicznościach”? Zawsze można powiedzieć, że stosujemy kary fizyczne w celu wychowawczym, tylko dla dobra dziecka, i w ten sposób próbować usprawiedliwić swój czyn i swoją... nieudolność wychowawczą. Zgadzam się natomiast z W. Skrzydło, który podkreśla, że konsekwencją wprowadzenia do Konstytucji ogólnego zakazu stosowania kar cielesnych jest to, iż kary cielesne nie mogą być wprowadzane czy stosowane nie tylko w ramach prawnie dopuszczalnego systemu kar, lecz także w stosunkach międzyludzkich. Autor uważa, że w związku z tym, iż sformułowanie art. 40 ustawy zasadniczej ma bardzo generalny charakter i nie dopuszcza żadnych ograniczeń $\mathrm{w}$ stosowaniu tego zakazu, to znajdzie on też zastosowanie w warunkach życia rodzinnego, w stosunkach między rodzicami a dziećmi. Wobec dzieci nie mogą być więc stosowane okrutne, nieludzkie czy poniżające traktowanie, ale i kary cielesne. Za takim pojmowaniem zdaniem Skrzydły przemawia ponadto fakt, że Konstytucja wiele razy akcentuje rolę rodziny, wychowania młodego pokolenia, a także wprowadza ochronę praw dziecka ${ }^{10}$.

Nie ulega jednak wątpliwości, iż w Polsce mimo wszystko istnieje prawna tolerancja fizycznego karcenia dzieci, która wynika z obecnego w polskim porządku prawnym pozaustawowego kontratypu wychowawczego karcenia. Wyróżniamy dwa typy karcenia.

Po pierwsze, karc e ni e słowne. Szerszy zakres ma dopuszczalność karcenia słownego. Dotyczy bowiem nie tylko stosunków rodzinnych, lecz także nagannego postępowania małoletnich w szkole czy na ulicy. Osobą karcącą może być już nie tylko ten, komu przysługuje władza rodzicielska nad dzieckiem, ale też wychowawca, a nawet osoba obca, co powinno ograniczać się do uzasadnionych przypadków.

Po drugie, karc en i e fi zy c zn e. Może ono być dopuszczalne, a więc wyłączające bezprawność, w bardzo wyjątkowych sytuacjach, które są uzasadnione szczególnymi okolicznościami, jedynie w stosunkach między rodzicami a dziećmi

${ }^{8}$ R. Terlecki, Kiedy wychowawcze karcenie nieletnich staje się przestęstwem?, www.serwisprawa.pl $>$ Stronagłówna $>$ Prawokarne (dostęp: 8.03.2017).

9 P. Czarnek, Karcenie małoletnich w świetle Konstytucji RP, [w:] Prawne aspekty..., s. 38.

10 W. Skrzydło, Komentarz do art. 40 Konstytucji Rzeczypospolitej Polskiej, [w:] idem, Konstytucja Rzeczypospolitej Polskiej. Komentarz, wyd. 4, Kraków 2002. 
i tylko w bardzo ograniczonym zakresie, adekwatnym do danego przypadku. Przy ocenie stanu faktycznego należy brać pod uwagę brzmienie innych ustaw, które wyraźnie zabraniają rodzicom stosowania kar cielesnych, w tym klapsów ${ }^{11}$.

Jak już wskazałam, karcenie może przybrać różnorodną postać: może to być karcenie słowne, mimiką lub gestem oraz karcenie fizyczne, co oznacza, iż poszczególne postaci karcenia mogą wyczerpywać znamiona takich przestępstw, jak zniewaga (art. 216 k.k.), naruszenie nietykalności cielesnej (art. 217 k.k.), pozbawienie wolności (art. 189 k.k.) czy zmuszenie do określonego działania lub zaniechania (art. 191 k.k.). Istnienie kontratypu pozbawia zachowania tego rodzaju przymiotu przestępczości. Nie każde jednak zachowanie podjęte przez osobę dorosłą wobec małoletniego będzie niekaralnym karceniem wychowawczym. Jak przyjmuje się w piśmiennictwie i judykaturze, do istoty karcenia należy cel wychowawczy i wyrządzenie dolegliwości dziecku (nieprzekraczające pewnego stopnia dolegliwości), można zatem mówić o karceniu tylko wtedy, gdy intencją przyświecającą sprawcy jest osiągnięcie określonych celów wychowawczych. Nie stanowi kontratypu karcenia zadawanie dolegliwości fizycznych dziecku bez powodu, w celu „odpłaty”, wyładowania frustracji czy też karcenie nadmierne, naruszające czynności narządu ciała lub powodujące rozstrój zdrowia bądź będące znęcaniem się (art. 207 k.k.) $)^{12}$.

Na gruncie nauk prawnych rysuje się współcześnie tendencja do całkowitego zakwestionowania dopuszczalności karcenia. Zwolennicy tej tezy powołują się często na jego nieskuteczność jako środka wychowawczego. Co ważne, w literaturze pedagogicznej i psychologicznej panuje obecnie zasadnicza zgoda co do znikomej skuteczności kar fizycznych jako środka wychowawczego ${ }^{13}$. Jednakże nauka i judykatura prawa karnego dokonały określenia pewnych granic, które nie mogą zostać przekroczone przez osoby karcące - mowa tu o warunkach, które muszą zostać łącznie spełnione, aby nie rodziły odpowiedzialności karnej po stronie sprawcy. Warunki te są następujące:

— po pierwsze, karcenie winno dotyczyć jedynie osoby małoletniej — niedopuszczalne jest karcenie wychowawcze osób pełnoletnich, chociaż w tej kwestii pojawiły się zdania odrębne;

- po drugie, działania karcące muszą być podejmowane wyłącznie w celu wychowawczym - celem działania osoby karcącej powinno być wpajanie i egzekwowanie właściwych zasad postępowania. Zastosowana kara winna mieć na względzie przede wszystkim interes osoby małoletniej, jej dobro oraz prawidłowy rozwój fizyczny i psychiczny. Osoba małoletnia musi wiedzieć, z jakiego powo-

11 www.adwokatkasprzak.pl/blog/pozostale/karcenie-dziecka+ (dostęp: 11.03.2017).

12 L. Świta, Przemoc jako metoda wychowawcza? Karcenie dzieci w świetle prawa międzynarodowego, $w$ orzecznictwie Europejskiego Trybunatu Praw Człowieka oraz w prawie polskim, „Studia Warmińskie” 2010, nr 47, s. 351-352.

${ }^{13}$ K. Kamińska, Zespót maltretowanego dziecka a kontratyp karcenia małoletnich, [w:] O przemocy w wychowaniu, red. M. Bednarska, Toruń 2007, s. 71. 
du została skarcona. Ta wiedza jest jej potrzebna do tego, aby na przyszłość nie popełniać podobnych przewinień. Karcone nie może być więc kilkumiesięczne dziecko, które nie ma zdolności do pojmowania tego rodzaju działania;

— po trzecie, środki podejmowane w celu skarcenia osoby małoletniej muszą być proporcjonalne do wagi przewinienia. Zastosowana kara musi być relatywna do niewłaściwego czynu dziecka oraz jego stopnia winy, jednym słowem — kara powinna być sprawiedliwa;

— po czwarte, karcenie powinno być miarkowane w swojej intensywności; działanie podejmowane przez karcącego nie może zagrażać zdrowiu fizycznemu bądź psychicznemu dziecka ani też wykraczać poza zakres akceptowanych sposobów oddziaływania;

— po piąte, karcenie musi być reakcją na określone zachowanie osoby małoletniej — nie można tego typu działań podejmować jedynie profilaktycznie;

— po szóste, karcenie powinno być wykonywane w zwyczajowo przyjęty sposób; karcenie nie może przyjmować dziwnych form, nawet jeżeli spełnione byłyby wszystkie wcześniej wskazane warunki;

— po siódme, prawo wykonywania czynności karcenia przysługuje wyłącznie rodzicom, oczywiście chodzi o rodzica wykonującego władzę rodzicielską ${ }^{14}$. Kodeks rodzinny i opiekuńczy stanowi, że dziecko pozostaje pod władzą rodzicielską aż do pełnoletniości. Władza ta przysługuje z założenia obojgu rodzicom, jednocześnie obejmuje prawo i obowiązek rodziców do wykonywania pieczy nad majątkiem i osobą dziecka i powinna być wykonywana zgodnie z jego dobrem i interesem społecznym. Rodzice wychowują dziecko i kierują nim. Mają obowiązek troszczenia się o fizyczny i duchowy rozwój dziecka oraz mają za zadanie przygotowanie go do życia w społeczeństwie. Kodeks rodzinny i opiekuńczy nie zawiera uregulowań dotyczących karcenia dzieci i sposobu wykonywania uprawnień rodzicielskich. Jeżeli rodzice nie mogą się porozumieć w kwestiach istotnych dotyczących dziecka, rozstrzygnięcie w tej materii należy do sądu opiekuńczego, który wraz z innymi organami państwowymi są obowiązani do udzielenia rodzicom pomocy w kwestii należytego wychowania dziecka, jeżeli taka pomoc jest rzeczywiście potrzebna. Sąd opiekuńczy kontroluje również sposób postrzegania przez rodziców kwestii dobra dziecka, gdyż nie wszyscy rozumieją to pojęcie prawidłowo. Wobec tego kwestia karcenia dzieci jest głównie rozpatrywana w stosunku do rodziców ${ }^{15}$.

W zakresie tego warunku istnieją jednak rozbieżności w poglądach doktryny. Na pytanie, komu przysługuje prawo karcenia, nie ma jednoznacznej odpowiedzi na gruncie doktryny. Dominujący wydaje się pogląd, wedle którego ze względu na szczególny węzeł rodzinnej bliskości występujący w stosunkach między spo-

${ }^{14}$ M. Morawska, Zakaz stosowania kar cielesnych a pozaustawowy kontratyp karcenia wychowawczego, „Prokuratura i Prawo” 2012, nr 10, s. 31-33.

15 A. Olszewska, Karcenie dzieci w polskim ustawodawstwie, „Niebieska Linia” 2009, nr 1 (60), s. 8-9; zob. też A. Grześkowiak, Prawo karne, Warszawa 2011, s. 136-137. 
krewnionymi, uprawnienie do karcenia mają jedynie rodzice i opiekunowie, a problem karcenia da się usprawiedliwić tylko w ramach rodziny. Wówczas karcenie jest przyjmowane przez nieletniego zupełnie inaczej, niż byłoby to w stosunku do osoby obcej. Zgodnie z tym stanowiskiem karcenie wychowawcze nie może być rozszerzone na nauczycieli czy wychowawców.

Wedle drugiego stanowiska, które ma charakter bardziej liberalny, istnieje ukłon ku możliwości objęcia uprawnieniem do karcenia także osoby spoza najbliższej rodziny, zastrzegając wszak jednocześnie warunek konieczności jego znacznego w tym zakresie ograniczenia. Prawo karcenia może być przekazane przez rodziców lub opiekunów innym osobom bądź wyraźnie, bądź w sposób dorozumiany. Jednakże taka delegacja nie jest równoznaczna z przeniesieniem na te podmioty pełni przysługujących im w tym zakresie praw, a to ze względu na to, że główny ciężar wychowania spoczywa w zasadzie na domu rodzinnym, a szkoła odgrywa rolę czynnika wprawdzie bardzo istotnego, ale tylko współdziałającego w procesie wychowawczym. Nauczyciel w wypadku trudności wychowawczych może się zwrócić o pomoc do rodziców ${ }^{16}$.

Trzeba dodać, iż w doktrynie dominuje pogląd, że umiejętności wychowawcze rodziców nie są warunkiem posiadania dzieci i jedynie rażące nadużycia w tej dziedzinie stanowią podstawę ingerencji organów państwa i społeczeństwa w tę sferę życia, zarezerwowaną głównie dla rodziny. Za prawną podstawę, z której wyprowadza się uzasadnienie kontratypizacji karcenia małoletnich, uznaje się przepis prawa rodzinnego, który wyposaża rodziców w atrybut władzy rodzicielskiej, co wiąże się ze zobowiązaniem ich do sprawowania pieczy nad dzieckiem i troski o jego prawidłowy rozwój (art. 95 § 1 k.r.o.). Uznaje się zatem, że w ramach sprawowania władzy rodzicielskiej nad dzieckiem dopuszczalne jest jego skarcenie.

Należy jednak raz jeszcze podkreślić, iż karane jest jedynie nadużycie karcenia, to jest przekroczenie granic zakreślonych dla prawa rodziców do karcenia małoletnich. Na gruncie prawa karnego za karcenie uznaje się czyn polegający na wyrządzeniu dziecku dolegliwości w celu uświadomienia mu naganności jego zachowania, ale i w celu wpłynięcia na jego zachowanie w ten sposób, aby naganny czyn nie miał miejsca w przyszłości ${ }^{17}$. R. Krajewski akcentuje ponadto, że zawsze należy przy tym pamiętać, że prawo karne ma charakter subsydiarny wobec innych dziedzin prawa, a skoro prawo rodzinne zawiera przedmiotowy zakaz, to prawo karne nie może tego nie uwzględniać, ponieważ stanowiłoby to przejaw sprzeczności wewnątrz systemu prawa jako całości w takim sensie, że przepis prawa rodzinnego i opiekuńczego zakazuje takich zachowań, a prawo karne wciąż chciałoby je tolerować na zasadzie pozaustawowej okoliczności uchylającej

16 I. Stachura, Karcenie wychowawcze i ryzyko sportowe. Próba analizy statusu normatywnego wybranych kontratypów pozaustawowych, „Czasopismo Prawa Karnego i Nauk Penalnych” 11, 2007, nr 2, s. 132-133.

17 S. Hypś, Ochrona rodziny w polskim prawie karnym, Lublin 2012, s. 164-165. 
bezprawność ${ }^{18}$. M. Mozgawa z kolei w ogóle negatywnie ocenia wprowadzenie do kodeksu rodzinnego i opiekuńczego zakazu stosowania kar cielesnych wobec dzieci, ponieważ jego zdaniem de facto taki zakaz już istniał poprzez inne przepisy kodeksu karnego (zakazujące na przykład naruszania nietykalności cielesnej, znęcania się, dokonywania uszczerbków na zdrowiu). W jego opinii należy pamiętać, że relacje rodzinne trudno poddają się ingerencji prawnej, a jeśli zamiarem państwa było wyeliminowanie klapsów z rodzicielskich metod wychowawczych, to lepszą drogą byłoby postawienie na szeroko zakrojone działania edukacyjne niż wprowadzenie zakazu prawnego, który i tak — jak pisze Mozgawa - nie zmieni mentalności istniejącej praktyki ${ }^{19}$. R. Krajewski podkreśla poza tym, że nie jest tak, iż wprowadzenie prawnego zakazu stosowania kar cielesnych wobec małoletnich miałoby automatycznie powodować niedopuszczenie innych postaci oddziaływania na nich, byleby nie polegały one na wymierzaniu kar fizycznych, co na nowo wyznacza granice kontratypu karcenia małoletnich. Przeciwna wykładnia, zakładająca, że z przedmiotowego zakazu można by wywieść zakaz jakiegokolwiek wychowawczego oddziaływania na małoletnich, które formalnie wyczerpywałoby znamiona czynu zabronionego, zwłaszcza zmuszania, znieważania czy pozbawiania wolności, jest nieuprawniona. Według Krajewskiego omawiany kontratyp nadal istnieje, $\mathrm{z}$ tą jednak różnicą w porównaniu ze stanem sprzed wprowadzenia zakazu stosowania kar fizycznych wobec dzieci, że nie obejmuje on uchylenia bezprawności ich stosowania. Wspomniany autor sugeruje, że być może powinno ulec zmianie określenie tej okoliczności uchylającej bezprawność w taki sposób, żeby nie było w nim mowy o karach cielesnych czy nawet o karceniu, które najbardziej kojarzy się ze stosowaniem kar fizycznych, a które można by zastąpić wskazaniem, że chodzi o wychowawcze oddziaływanie na dzieci ${ }^{20}$.

Z perspektywy prawa karnego dodanie do kodeksu rodzinnego i opiekuńczego art. $96^{1} \mathrm{~W}$ żaden sposób nie wpłynęło na ustalenie granic kontratypu. Ustawodawca nie chce narzucać rodzicom konkretnego modelu wychowawczego, który mieliby powielać. Przepis ten jednakże zakazuje wszelkich form karcenia, nawet przysłowiowego klapsa, i tego rodzice powinni przestrzegać. Natomiast dobór przez opiekunów czy rodziców metod wychowawczych jest niezmiernie delikatną kwestią, trzeba zatem tylko promować, pokazywać właściwe zachowania w tej sprawie już w efekcie istnienia prawnego zakazu stosowania wobec dzieci kar fizycznych ${ }^{21}$.

18 R. Krajewski, Kontratyp karcenia małoletnich po wprowadzeniu prawnego zakazu stosowania wobec nich kar cielesnych, „Palestra” 2012, nr 1-2, s. 55.

19 M. Mozgawa, Prawo karne materialne. Część ogólna, Warszawa 2016, s. 296-297.

20 R. Krajewski, Kontratyp karcenia..., s. 52-53.

${ }_{21}$ M. Jończyk, Kontratyp a karcenie małoletnich w polskim prawie karnym, „Zeszyty Naukowe Instytutu Administracji AJD w Częstochowie" 2016, nr 1 (13), s. 51. 


\section{KARCENIE DZIECI A KONTRATYP POZAUSTAWOWY}

W nauce prawa karnego dominował zatem, i wciąż dominuje, pogląd, w myśl którego karcenie dzieci należy do okoliczności wyłączających bezprawność, czyli kontratypu ${ }^{22}$. Podkreślić należy, że kontratyp karcenia małoletnich nie został uregulowany w żadnym akcie prawnym. Zaliczany jest do tak zwanych kontratypów pozaustawowych. S. Różycka-Jaroś wyraża jednak pewne wątpliwości co do tego, czy działania podjęte w ramach karcenia, które naruszały określone dobra dziecka, chronione przez normy prawa karnego, rzeczywiście mogły wyłączać przestępność czynu właśnie na zasadzie kontratypu pozaustawowego. Konstrukcja pozaustawowych kontratypów służy do tego, aby nie karać zachowań niegroźnych, zwyczajowo akceptowanych z punktu widzenia polityki kryminalnej. I w tym miejscu pojawiają się wątpliwości wymienionej autorki. Zastanawia się ona bowiem, czy biorąc pod uwagę wiedzę z zakresu współczesnej psychologii, pedagogiki i psychiatrii, dotyczącą skutków stosowania takich metod wychowawczych, jak na przykład kary cielesne, można było tak długo uznawać, że jest to faktycznie czyn niegroźny. Mając na uwadze pogląd współczesnej pedagogiki na temat nieefektywności stosowania względem dzieci kar cielesnych czy innych metod poniżających ich godność, autorka stwierdza, że nie da się uzyskać żadnego ekwiwalentu, gdyż nie można osiągnąć docelowo odpowiednich skutków wychowawczych. Różycka-Jaroś wskazuje ponadto, że podstawy zanegowania kontratypu karcenia dziecka jako okoliczności uchylającej bezprawność czynu karcącego dotyczą:

— niewystępowania przesłanki funkcjonowania każdego kontratypu, w tym kontratypu karcenia dzieci, dotyczącej niekarania zachowań niegroźnych ze względu na udowodnioną szkodliwość czynów, stanowiących karcenie naruszające nietykalność cielesną oraz inne dobra osobiste dziecka;

- niewystępowania przesłanki dającej możliwość legitymizacji karcenia dziecka na zasadach kolizji dóbr, ze względu na nieadekwatność, a nawet niemożliwość ustalenia dobra uzyskanego w zamian za poświęcenie dobra w postaci przysporzenia cierpień fizycznych i psychicznych;

— niemożliwości dalszego tolerowania zwyczaju bicia dzieci, z którego prawo karne wywodziło kontratyp karcenia;

${ }^{22}$ Należy w ogóle wspomnieć, że pojęcie kontratypu do polskiej nauki prawa karnego wprowadził W. Wolter, który przez „kontratyp” rozumiał te okoliczności, które powodują, że czyn, mimo iż wypełnia znamiona czynu zabronionego, nie staje się czynem bezprawnym - idem, O kontratypach i braku społecznej szkodliwości czynu, „Państwo i Prawo” 1963, nr 10, s. 507. W literaturze prawniczej, ale i w języku prawniczym, określenie „kontratyp” używane jest w stosunku do okoliczności wyłączających bezprawność czynu, a więc takich, przy których czyn wypełniający znamiona czynu zabronionego nie jest jednak nim w rzeczywistości, gdyż na mocy przepisu prawnego lub utartej praktyki postępowania działania takie uważane są za zgodne z prawem - L. Gardocki, Prawo karne, Warszawa 2007, s. 111. Kontratypy dzielą się na ustawowe (skodyfikowane) i pozaustawowe, określane także jako nieskodyfikowane - R. Krajewski, Kontratyp karcenia ..., s. 49. 
- niewystępowania najistotniejszej przesłanki istnienia tego kontratypu w postaci osiągnięcia celu wychowawczego ze względu na udowodnioną niemożliwość osiągnięcia tegoż celu, stosując kary cielesne lub poniżające dziecko ${ }^{23}$.

Zdaniem F. Ciepłego nie można zapominać, że kontratyp karcenia małoletnich nie odnosi się wyłącznie do ich fizycznego karania. Wprowadzenie ustawowego zakazu karcenia dzieci nie może być jednak podstawą do całkowitego odrzucenia kontratypu przez doktrynę lub judykaturę. Kontratyp ten nie wyłącza wszak odpowiedzialności karnej tyko za klapsa, lecz także za wiele innych naruszeń norm prawa karnego, które są uzasadnione wychowawczo. Bez zastosowania konstrukcji kontratypu karcenia dzieci za bezprawne można byłoby uznać na przykład ukaranie dziecka zakazem oglądania telewizji albo niewypuszczenie dziecka z domu po określonej godzinie. Zakaz lub dopuszczalność stosowania kar fizycznych wobec małoletnich nie może bezpośrednio wpływać na pojęcie kontratypu karcenia dzieci, ponieważ ma on o wiele szerszy zakres niżeli jedynie klaps dany dziecku za jego niewłaściwe zachowanie ${ }^{24}$. Ciepły wskazuje ponadto, że

jeżeli jest prawdą, że stosowanie kar cielesnych wobec dzieci nie służy ich dobru (co ciągle wydaje się kwestią dyskutowaną), to przyjęcie, iż fizyczne karcenie dzieci nie jest kontratypem, a więc nie posiada cechy legalności kryminalnej, będzie służyć lepiej kształtowaniu świadomości moralnej i pedagogicznej społeczeństwa, jak również chyba skuteczniej zabezpieczać dziecko przed być może rzadkimi, ale jednak sporadycznie występującymi nadużyciami w środowisku rodzinnym ${ }^{25}$.

Słusznie zauważa w tym kontekście M. Jończyk, że uruchamianie prawnokarnej ochrony jest rozwiązaniem ostatecznym, drastycznym i nie zawsze właściwym, służącym dobru dzieci i rodziców. Z jednej strony, wyrok karny może przecież przerwać cierpienie dziecka i oswobodzić je od rodziców, którzy są jego oprawcami. W takiej sytuacji pracownik socjalny, jeśli mamy do czynienia z bezpośrednim zagrożeniem zdrowia lub życia dziecka, może odebrać je rodzicom i umieścić na przykład u innej niezamieszkującej wspólnie osoby najbliższej. Z drugiej zaś strony, urywa i tak już nieco nadszarpnięte więzi rodzinne. Bardzo istotne jest więc, aby ta ingerencja zawsze była wyważona. Jednym natomiast $\mathrm{z}$ najlepszych sposobów jest poddanie rodziców kontroli i określonym ograniczeniom przewidzianym przez przepisy kodeksu rodzinnego i opiekuńczego, a nie karanie ich w trybie kodeksu karnego. Oczywiście jeśli sytuacja tego wymaga, jest tak drastyczna, że wskazane rozwiązanie nie wystarcza, to ingerencja karna jest uzasadniona i wyrok powinien obejmować również pozbawienie rodzica władzy rodzicielskiej, ale i zakaz zbliżania się do dziecka ${ }^{26}$.

23 S. Różycka-Jaroś, op. cit., s. 74-81.

${ }^{24}$ F. Ciepły, op. cit., s. 262.

25 F. Ciepły, Problem legalności kryminalnej karcenia cielesnego małoletnich z perspektywy zasad wyktadni historycznoprawnej, [w:] Prawne aspekty..., s. 95.

${ }^{26}$ M. Jończyk, op. cit., s. 55. 
Reasumując, należy stwierdzić, iż z całą pewnością zakaz stosowania kar cielesnych wpłynął na granice pozaustawowego kontratypu karcenia, w sposób wyraźny wyłączając z jego zakresu wszystkie formy karcenia cielesnego. Bez wątpienia skuteczność wyrażonego w kodeksie rodzinnym i opiekuńczym zakazu w praktyce stanowi największy problem. Bardzo ważna w tej sytuacji jest właściwa i skuteczna kampania społeczna, mająca na celu kształtowanie w tym zakresie świadomości moralnej społeczeństwa. Zmiana podejścia ludzi jest bowiem podstawą eliminacji procederów karcenia fizycznego. Ludzie mający większą wiedzę na temat szeroko pojętej przemocy względem dzieci mogą szybciej reagować na niepokojące sygnały. Tym samym, ludzie stosujący nawet tak zwane klapsy spotkają się z dezaprobatą ze strony społeczeństwa, będą zdawali sobie sprawę z tego, że ich postępowanie stoi w niezgodzie z obowiązującym prawem i takich sytuacji będą starali się unikać. Edukacyjna kampania społeczna niewątpliwie skutecznie zmieniłaby podejście społeczeństwa do stosowania kar cielesnych, a gdyby tak się stało, moglibyśmy powiedzieć, że przepis art. $96^{1}$ k.r.o. jest regulacją skuteczną.

\section{PROHIBITION ON CORPORAL PUNISHMENT APPLICATION AND EXCUSE OF EDUCATIONAL REPROVING}

\section{Summary}

The paper studies relationships between the prohibition to apply corporal punishment under the Family and Guardianship Code, Article $96^{1}$, and excuse of reproving for educational purposes, this excuse working in criminal law. The analysis is provided of issues connected with the subject matter of this article, results of the prohibition under the Family and Guardianship Code, Article $96^{1}$ on the excuse are described, and conclusions concerning the effectiveness of the prohibition are formulated. Practical significance of the issues tackled in this article results from the common nature of the phenomenon of using various forms of reproving children.

Keywords: the prohibition to apply corporal punishment, off-law valid excuse of reproving for educational purposes, family law, criminal law

\section{BIBLIOGRAFIA}

Bojarski T., Zakres kontratypu karcenia matoletnich w polskim prawie karnym, [w:] Prawne aspekty karcenia matoletnich, red. F. Ciepły, Warszawa 2011.

Ciepły F., Partnerstwo w rodzinie a prawnokarny kontratyp karcenia małoletnich, [w:] Partnerstwo w rodzinie. Istota i uwarunkowania relacji między rodzicami a dziećmi, red. J. Truskolaska, Lublin 2009.

Ciepły F., Problem legalności kryminalnej karcenia cielesnego małoletnich z perspektywy zasad wyktadni historycznoprawnej, [w:] Prawne aspekty karcenia matoletnich, red. F. Ciepły, Warszawa 2011.

Czarnek P., Karcenie małoletnich w świetle Konstytucji RP, [w:] Prawne aspekty karcenia małoletnich, red. F. Ciepły, Warszawa 2011.

Przegląd Prawa i Administracji CXX, 2020, cz. 1 i 2

(C) for this edition by CNS 
Frączek Z., Nagrody i kary w wychowaniu rodzinnym, „Pedagogika Rodziny” 2014, nr 4.

Gardocki L., Prawo karne, Warszawa 2007.

Grześkowiak A., Prawo karne, Warszawa 2011.

Hypś S., Ochrona rodziny w polskim prawie karnym, Lublin 2012.

Jończyk M., Kontratyp a karcenie małoletnich w polskim prawie karnym, „Zeszyty Naukowe Instytutu Administracji AJD w Częstochowie” 2016, nr 1 (13).

Kamińska K., Zespół maltretowanego dziecka a kontratyp karcenia małoletnich, [w:] O przemocy w wychowaniu, red. M. Bednarska, Torun 2007.

Krajewski R., Karcenie dzieci. Pespektywa prawna, Warszawa 2010.

Krajewski R., Kontratyp karcenia małoletnich po wprowadzeniu prawnego zakazu stosowania wobec nich kar cielesnych, „Palestra” 2012, nr 1-2.

Morawska M., Zakaz stosowania kar cielesnych a pozaustawowy kontratyp karcenia wychowawczego, „Prokuratura i Prawo” 2012, nr 10.

Mozgawa M., Prawo karne materialne. Część ogólna, Warszawa 2016.

Olszewska A., Karcenie dzieci w polskim ustawodawstwie, „Niebieska Linia” 2009, nr 1 (60).

Różycka-Jaroś S., Karcenie dzieci - czyn zabroniony czy okoliczność uchylająca bezprawność, Warszawa 2012.

Ruszel M.E., Zwyczajowe formy karcenia wychowawczego dzieci w spoleczeństwie polskim, [w:] Prawne aspekty karcenia małoletnich, red. F. Ciepły, Warszawa 2011.

Skrzydło W., Komentarz do art. 40 Konstytucji Rzeczypospolitej Polskiej, [w:] idem, Konstytucja Rzeczypospolitej Polskiej. Komentarz, wyd. 4, Kraków 2002.

Stachura I., Karcenie wychowawcze i ryzyko sportowe. Próba analizy statusu normatywnego wybranych kontratypów pozaustawowych, „Czasopismo Prawa Karnego i Nauk Penalnych” 11, $2007, \mathrm{nr} 2$.

Świta L., Przemoc jako metoda wychowawcza? Karcenie dzieci w świetle prawa międzynarodowego, w orzecznictwie Europejskiego Trybunału Praw Człowieka oraz w prawie polskim, „Studia Warmińskie" 2010, nr 47.

Terlecki R., Kiedy wychowawcze karcenie nieletnich staje się przestępstwem?, www.serwisprawa. $\mathrm{pl}>$ Stronagłówna $>$ Prawokarne.

Wolter W., O kontratypach i braku społecznej szkodliwości czynu, „Państwo i Prawo” 1963, nr 10. www.adwokatkasprzak.pl/blog/pozostale/karcenie-dziecka+.

Wyrok Trybunału Konstytucyjnego z dnia 1 czerwca 1999 roku, sygn. SK 20/98, OTK 1999, nr 5, poz. 93. 